\title{
Properties of Barium Titanium Silicate Glasses
}

\author{
Given W. Cleek and Edgar H. Hamilton
}

\begin{abstract}
The glass-forming region of the $\mathrm{BaO}_{-} \mathrm{TiO}_{2}-\mathrm{SiO}_{2}$ system has been determined. The refractive index, $n_{D}$, nu value, liquidus temperature, and transmittances in the near infrared have been measured. Also measured for representative glasses were linear coefficient of thermal expansion, deformation temperature, chemical durability, and hygroscopicity. A number of stable glasses were found, which have high refractive indices, good infrared transmittances, and high deformation temperatures, and which are unique in their resistance to attack by both acids and alkalis.
\end{abstract}

\section{Introduction}

The development of infrared detecting devices has created a demand for glasses for their construction. Many of these devices operate in the near infrared at the wavelengths of the so-called atmospheric windows, where atmospheric transmittance is high. The windows for which glasses are being developed are those at wavelengths of roughly 2.0 to 2.4 and 3.5 to $6.0 \mu$.

The requirements for the glasses include high transmittance at the wavelengths of interest, and good chemical durability. In addition, for refracting optics, glasses having high refractive indices over the range of about 1.80 to 2.00 , and a range of dispersions for each index, are needed. $\mathrm{B}_{2} \mathrm{O}_{3}$ and $\mathrm{P}_{2} \mathrm{O}_{5}$ are not desirable as constituents of infrared transmitting glasses, as they cause rather strong absorption bands beyond wavelengths of about $2.75 \mu[1]{ }^{3}$ The silicate glasses, in general, do not transmit beyond about $5 \mu$, presumably due to the Si-O bond, which absorbs at $4.45 \mu[2]$. Germanate glasses transmit to about $6 \mu[1]$, but $\mathrm{GeO}_{2}$ is a scarce and expensive material so that it is not readily available as a constituent of glass. Another group of oxide glasses, which contain no so-called "glass former," are the calcium aluminate glasses [1], which also transmit to about $6 \mu$. They require very high melting temperatures, devitrify easily, and have poor chemical durability.

Most high-index glasses presently available are either extra-dense flint glasses, which have a high $\mathrm{PbO}$ content, or rare-earth borate glasses [3]. The extra-dense flint glasses have fairly good infrared transmittances, cutting off, as do most silicate glasses, at about $5 \mu$. They have high refractive indices, but their chemical durability is poor. The $\mathrm{B}_{2} \mathrm{O}_{3}$ content of most rare-earth glasses makes them useless for infrared applications.

Upon consideration of the above factors, it was decided that silicate glasses appear to offer the best possibilities for general use if other components could be found to impart the desired properties to the glasses. A system on which little information was available, but which appeared promising from the point of view of high refractive index and good infrared transmittance if glass-forming compositions could be found, was the ternary $\mathrm{BaO}-\mathrm{TiO}_{2}-\mathrm{SiO}_{2}$

1 The work described in this report was sponsored by the Bureau of Ordnance, Department of the Navy.

2 Presented at the Fifty-Seventh Annual Meeting, The American Ceramic Society, Cincinnati, Ohio, April 27, 1955 (Glass Division No. 32)

3 Figures in brackets indicate the literature references at the end of this paper system. The phase equilibrium diagram has not been determined, but information is available on the binary sides of the ternary system $[4,5,6]$. Rase and Roy have determined the liquidus temperatures and phase relations along the line $\mathrm{BaO} \cdot \mathrm{TiO}_{2}-$ $\mathrm{SiO}_{2}$ in the ternary diagram [7]. This information was very useful in selecting compositions in the ternary system that could be melted and cooled as glasses.

\section{Experimental Procedure}

The glasses were made in 500-g melts from batch materials of sufficient purity to satisfy the requirements for the production of optical glass. The standard procedure was to melt the batches in platinum crucibles, $2 \frac{1}{2}$ in. in diameter by 3 in. deep. After the batch was melted, the melt was stirred for $2 \mathrm{hr}$ with a motor-driven platinum-10-percentrhodium double-bladed propeller-type stirrer. It was then poured into a heated metal mold to form a block about $\frac{1}{2} \mathrm{in}$. thick. When sufficiently rigid, the glass block was transferred to an electric muffle furnace, which was cooled to room temperature in approximately $18 \mathrm{hr}$. Only those compositions that could be melted below $1,500^{\circ} \mathrm{C}$ and in which no appreciable devitrification occurred during cooling were considered to produce glasses. These experimental conditions were used to define the glassforming region of the system, and no attempt was made to enlarge the region by melting at higher temperatures or by cooling the melts more rapidly to avoid devitrification.

A softening temperature for each glass was determined by a gradient method [8]. A fiber of glass, 0.4 to $0.6 \mathrm{~mm}$ in diameter, was supported at approximately $1 / 2$-in. intervals on a platinum holder and placed in a known temperature gradient for 20 to 30 min. From the position at which the fiber sagged between supports, the softening temperature could be determined to $\pm 10 \mathrm{deg} \mathrm{C}$. The softening temperature, so determined for these glasses, was found to be from 40 to $60 \mathrm{deg} \mathrm{C}$ above the deformation point as determined by the interferometric thermalexpansion method [9]. Using this information, the glasses were annealed by heating for 4 to $6 \mathrm{hr}$ at a temperature about $60 \mathrm{deg} \mathrm{C}$ below their softening temperature and then cooling at a rate of $2 \frac{1}{2} \mathrm{deg} / \mathrm{hr}$ to $350^{\circ} \mathrm{C}$. It is believed that this treatment yielded glasses of comparable annealing, inasmuch as the temperature at which equilibrium was obtained would be a function of the composition and rate of cooling. 
The liquidus temperature of each glass was determined by a temperature-gradient method [10].

Refractive-index determinations were made on polished annealed samples of the glasses in the form of $60^{\circ}$ prisms for the $\mathrm{C}, \mathrm{D}$, and $\mathrm{F}$ lines by the NBS Optical Instruments Section. The spectral transmittances of the glasses were determined from 1.0 to $6.0 \mu$ by the NBS Radiometry Section, with a model 21 double-beam Perkin-Elmer infrared spectrometer.

The chemical durability of the glasses was determined by an interferometric method developed by Hubbard and Hamilton [11]. Cloth-polished samples were immersed about one-half their lengths in solutions buffered to the desired values of $p \mathrm{H}$. After $6 \mathrm{hr}$ of exposure at $80^{\circ} \mathrm{C}$ the samples were removed from the solutions and viewed through an optical flat with monochromatic light. Any shift in the inter- ference bands as they pass from the unexposed to the exposed portion of a sample is proportional to the amount of attack by the buffered solution and is, therefore, a measure of the chemical durability of the glass.

The linear thermal expansions and the deformation temperatures of several of the glasses were determined by an interferometric method described by Saunders $[9]$.

\section{Results}

\subsection{Glass-Forming Area of the $\mathrm{BaO}-\mathrm{TiO}_{2}-\mathrm{SiO}_{2}$ System}

The compositions of all melts made in the system are given in table 1 and are plotted in the ternary

Table 1. Ternary $\mathrm{BaO}-\mathrm{TiO}_{2}-\mathrm{SiO}_{2}$ Compositions

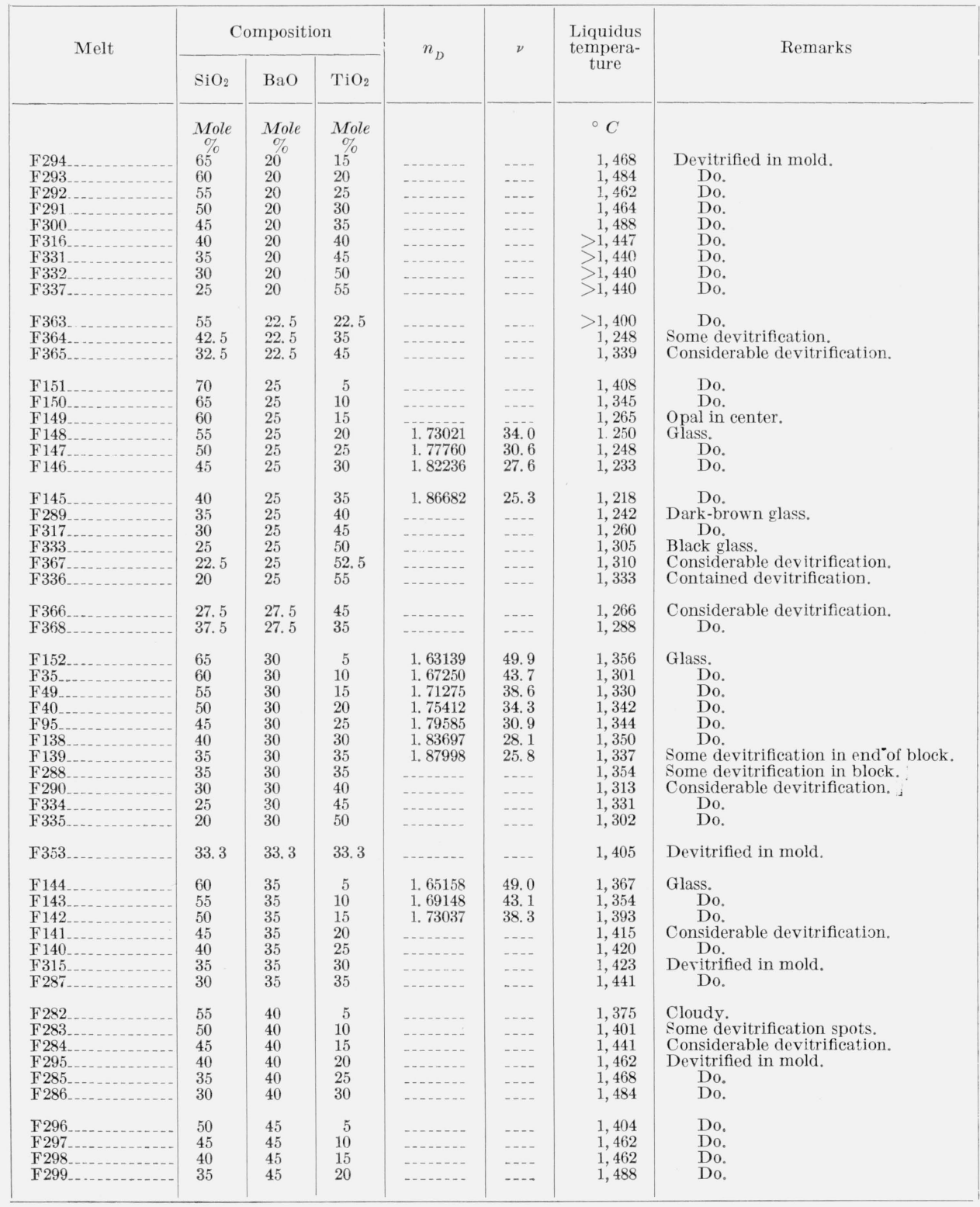


diagram in figure 1. As may be seen from the figure, the longest $\mathrm{BaO}$ isopleth along which glasses are formed is the 25 mole percent $\mathrm{BaO}$ line. Although glasses are not formed on this line to the $\mathrm{BaO}-\mathrm{SiO}_{2}$ binary, glass formation begins at about 20 mole percent of $\mathrm{TiO}_{2}$ and extends to relatively high concentrations of $\mathrm{TiO}_{2}$. This line of glass formation seems to follow a valley in the liquidus surface, as may be seen from table 1 .

The color of the glasses changed very markedly as the $\mathrm{TiO}_{2}$ content was increased. Those containing up to about 15 mole percent of $\mathrm{TiO}_{2}$ were nearly colorless, whereas those containing intermediate amounts, from 20 to 35 mole percent of $\mathrm{TiO}_{2}$, were orange colored, and the others having above 40 mole percent of $\mathrm{TiO}_{2}$ were dark brown to black. Evidently, as the $\mathrm{TiO}_{2}$ content is increased, the absorption increases at the shorter wavelengths in the visible region, and at higher $\mathrm{TiO}_{2}$ concentrations very little visible light is transmitted.

\subsection{Liquidus Temperature}

The liquidus temperature for each composition is given in table 1 . It will be noticed from the table that in no case was a glass formed from a composition that had a liquidus temperature greater than $1,400^{\circ}$ C. The lowest liquidus temperatures were found along the 25-mole-percent $\mathrm{BaO}$ isopleth, which is also the longest line of glass formation in the system. Furthermore, the shape of the liquidus curve of the 25-mole-percent $\mathrm{BaO}$ series in the areas of best glass formation is relatively flat, indicating a high degree of dissociation of the primary phase at the liquidus temperature [12]. Probably, the ease of glass formation is related to the degree of dissociation of the primary phase in the melt, because a similar observation was made for the $\mathrm{BaO}-\mathrm{B}_{2} \mathrm{O}_{3}-\mathrm{SiO}_{2}$ glasses [8]. In the latter system, the glasses whose compositions lie in the $3 \mathrm{BaO} \cdot 3 \mathrm{~B}_{2} \mathrm{O}_{3} \cdot 2 \mathrm{SiO}_{2}$ primary field, which has a flat liquidus curve, were the ones that were melted and homogenized with the least difficulty and had the least tendency to devitrify.

\subsection{Refractive Indices and Dispersions}

The refractive indices, $n_{D}$, and $\nu$ values are plotted in figure 2 for the three $\mathrm{BaO}$ isopleths along which glasses were obtained. The values of $n_{D}$ varied from 1.63139 to 1.87998 , and $\nu$ from 49.9 to 25.3 . The refractive-index values appear to be linear functions of composition. The plots of the $\nu$ values definitely show curvature.

\subsection{Infrared Transmittances}

Figures 3 to 9 , inclusive, give the transmittances for $2-\mathrm{mm}$ thicknesses of the ternary glasses over the spectral range 1 to $5 \mu$. The figures compare glasses of constant $\mathrm{TiO}_{2}$ content. In general, the glasses giving the highest transmittance at $4 \mu$ lie on the 30 -mole-percent $\mathrm{BaO}$ isopleth up to a $\mathrm{TiO}_{2}$ concentration of 25 mole percent, then the compositions shift to the 25-mole-percent $\mathrm{BaO}$ isopleth. There are considerable differences in the transmittances of the various glasses, but no simple relationship between transmittance and composition is readily evident.

\subsection{Chemical Durability and Hygroscopicity}

The values of chemical durability of five representative ternary glasses are given in table 2 and are plotted as a function of $p \mathrm{H}$ in figure 10. All values are for $6 \mathrm{hr}$ of exposure at $80^{\circ} \mathrm{C}$. As may be seen from the figure, the glass containing 60 mole percent of $\mathrm{SiO}_{2}$ is attacked in the alkaline range. $\mathrm{As} \mathrm{SiO}_{2}$ is replaced by $\mathrm{TiO}_{2}$, the attack in this range is decreased, and although slight attack or swelling is noticed at $p \mathrm{H} \mathrm{2}$, the glasses containing 20 mole percent, and more, of $\mathrm{TiO}_{2}$ show no attack in the alkaline range.

The hygroscopicity [13], or the tendency of a powdered-glass sample to absorb water in a humid atmosphere, was very low for the samples of the ternary glasses on which determinations were made. The values obtained were, in all cases, equal or less than fused silica, which was used for purposes of comparison. These data are given in table 2 and plotted in figure 11.

The resistance of these glasses to chemical attack and their low hygroscopicity make them unique as compared to known oxide glasses.

TABLE 2. Hygroscopicity and chemical durability of $\mathrm{BaO}$ $\mathrm{TiO}_{2}-\mathrm{SiO}_{2}$ glasses

\begin{tabular}{|c|c|c|c|c|c|c|c|c|}
\hline \multirow{2}{*}{ Melt } & \multicolumn{2}{|c|}{$\begin{array}{l}\text { Water } \\
\text { sorbed }\end{array}$} & \multicolumn{6}{|c|}{$\begin{array}{l}\text { Surface alteration, a fringes, at } p H- \\
\text { (exposures, } 6 \text { hr at } 80^{\circ} \text { C) }\end{array}$} \\
\hline & $1 \mathrm{hr}$ & $2 \mathrm{hr}$ & 2.0 & 4.1 & 6.0 & 8.2 & 10.2 & 11.8 \\
\hline $\begin{array}{l}\text { F35 } \\
\text { F49 } \\
\text { F40 } \\
\text { F95 } \\
\text { F138 }\end{array}$ & $\begin{array}{r}\mathrm{mgl} \\
\mathrm{cm}^{3} \\
5.7 \\
6.1 \\
5.2 \\
\end{array}$ & $\begin{array}{r}m g / \\
c m^{3} \\
10.0 \\
9.1 \\
8.2 \\
-\end{array}$ & $\begin{array}{r}\mathrm{ND} \\
\mathrm{ND} \\
1 / 10 \mathrm{~A} \\
2 / 10 \mathrm{~S} \\
1 / 10 \mathrm{~S}\end{array}$ & $\begin{array}{l}\text { ND } \\
\text { ND } \\
\text { ND } \\
\text { ND } \\
\text { ND }\end{array}$ & $\begin{array}{l}\text { ND } \\
\text { ND } \\
\text { ND } \\
\text { ND } \\
\text { ND }\end{array}$ & $\begin{array}{l}\text { ND } \\
\text { ND } \\
\text { ND } \\
\text { ND } \\
\text { ND }\end{array}$ & $\begin{array}{l}1 / 2 A \\
\text { ND } \\
\text { ND } \\
\text { ND } \\
\text { ND }\end{array}$ & $\begin{array}{c}2 \mathrm{~A} \\
2 / 10 \mathrm{~A} \\
\mathrm{ND} \\
\mathrm{ND} \\
\mathrm{ND}\end{array}$ \\
\hline $\begin{array}{l}\text { Corning } 7740 \\
\text { Fused } \mathrm{SiO}_{2}\end{array}$ & $\begin{array}{r}15.9 \\
6.2\end{array}$ & $\begin{array}{l}28.3 \\
12.1\end{array}$ & $\begin{array}{l}\text { ND } \\
\text { ND }\end{array}$ & $\begin{array}{l}\text { ND } \\
\text { ND }\end{array}$ & $\begin{array}{l}\text { ND } \\
\text { ND }\end{array}$ & $\begin{array}{l}\text { DA } \\
\text { ND }\end{array}$ & $\begin{array}{l}1 / 4 \mathrm{~A} \\
\mathrm{DA}\end{array}$ & $\begin{array}{c}13 / 4 \mathrm{~A} \\
1 / 2 \mathrm{~A}\end{array}$ \\
\hline
\end{tabular}

a ND, No detectable attack; A, attack of surface; S, swelling of surface; DA, detectable, but not measurable attack.

\subsection{Thermal Expansion and Deformation Temperatures}

The linear coefficient of thermal expansion has been determined for only three representative ternary glasses. The values obtained were 9 or $10 \times 10^{-6}$, which is near the values of most commercial sodalime-silica glasses. The deformation temperatures are somewhat higher than the usual values for silicate glasses. The expansion curves for the three glasses are plotted in figure 12. The deformation temperatures varied from $767^{\circ} \mathrm{C}$ for glass F35, containing 10 mole percent of $\mathrm{TiO}_{2}$, to $791^{\circ} \mathrm{C}$ for glass $\mathrm{F} 138$, having 30 mole percent of $\mathrm{TiO}_{2}$. 


\section{Summary}

The glass-forming region of the $\mathrm{BaO}-\mathrm{TiO}_{2}-\mathrm{SiO}_{2}$ system has been determined. The liquidus temperature, refractive indices and dispersions, and infrared transmittances of the glasses have been measured. The chemical durability and hygroscopicity, and linear thermal expansion of selected glasses have been determined. Glasses in this system are unique as compared to most glasses in that they have a high deformation temperature, exceptional chemical durability, and very low hygroscopicity.

\section{References}

[1] Francis W. Glaze, Transmittance of infrared energy by glasses, Bul. Am. Ceram. Soc. 34, 291 (1955).

[2] Jack M. Florence, Charles C. Allshouse, Francis W. Glaze, and Clarence H. Hahner, Absorption of nearinfrared energy by certain glasses, J. Research NBS 45, 121 (1950) RP2118.

[3] C. J. Phillips, Glass the miracle maker, p. 116 (Pitman Publishing Corp., 1948).

[4] D. E. Rase and Rustum Roy, Phase equilibria in the system $\mathrm{BaO}_{-} \mathrm{TiO}_{2}$, J. Am. Ceram. Soc. 38, 102 (1955).
[5] E. N. Bunting, Phase equilibria in the systems $\mathrm{TiO}_{2}$ $\mathrm{TiO}_{2}-\mathrm{SiO}_{2}$ and $\mathrm{TiO}_{2}-\mathrm{Al}_{2} \mathrm{O}_{3}$, BS J. Research 11, 719 (1933) RP619. R. W. Ricker and F. A. Hummel, Reactions in the system $\mathrm{TiO}_{2}-\mathrm{SiO}_{2}$; revision of the phase diagram, J. Am. Ceram. Soc. 34, 271 (1951). R. C. De Vries, Rustum Roy, and E. F. Osborn, The system $\mathrm{TiO}_{2}-\mathrm{SiO}_{2}$, Trans. Brit. Ceram. Soc. 53, 525 (1954).

[6] P. Eskola, The silicates of strontium and barium, Am. J. Sci., 5th series, 4, 331 (1922). J. W. Grieg, Immiscibility of silicate melts, Am. J. Sci., 5th series, 13, 1 (1927).

[7] D. E. Rase and Rustum Roy, Phase equilibria in the system $\mathrm{BaTiO}_{3}-\mathrm{SiO}_{2}$, J. Am. Ceram. Soc. 38, 389 (1955).

[8] Edgar H. Hamilton, G. W. Cleek, and O. H. Grauer, Some properties of glasses in the $\mathrm{BaO}-\mathrm{B}_{2} \mathrm{O}_{3}-\mathrm{SiO}_{2}$ system and a theory of glass structure (unpublished manuscript).

[9] James B. Saunders, An apparatus for photographing interference phenomena, J. Research NBS 35, 157 (1945) RP1668.

[10] Oscar H. Grauer and Edgar H. Hamilton, An improved apparatus for the determination of liquidus temperatures and rates of crystal growth in glasses, J. Research NBS 44, 495 (1950) RP2096.

[11] Donald Hubbard and Edgar H. Hamilton, Studies of the chemical durability of glass by an interferometric method, J. Research NBS 27,143 (1941) RP1409.

[12] John E. Ricci, The phase rule and heterogeneous equilibrium, p. 123 (D. Van Nostrand Co., Inc., New York, N. Y., 1951).

[13] Donald Hubbard, Hygroscopicity of optical glasses as an indicator of serviceability, J. Research NBS $\mathbf{3 6}, 365$ (1946) RP1706.

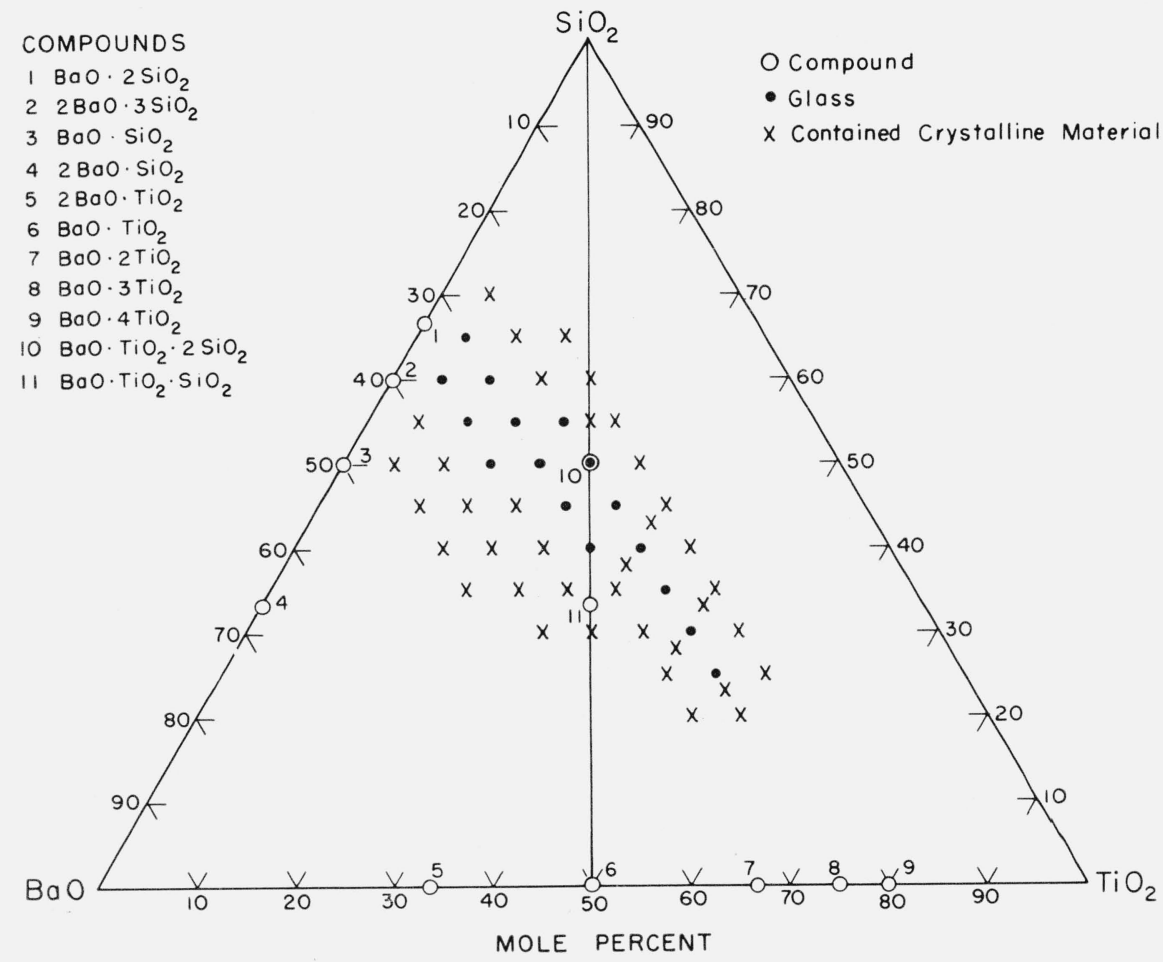

Figure 1. Compositions (in mole percent) studied in the system $\mathrm{BaO}-\mathrm{TiO}_{2}-\mathrm{SiO}_{2}$. 

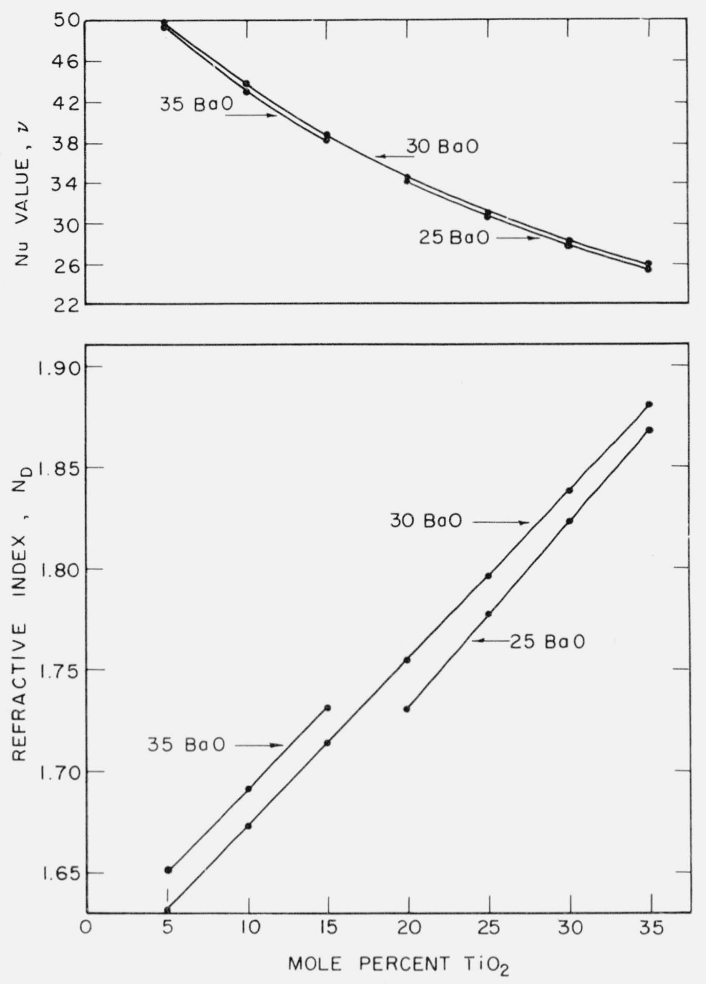

Figure 2. Plot of refractive index and nu value as a function of composition for the glass-forming compositions in the $\mathrm{BaO}-\mathrm{TiO}_{2}-\mathrm{SiO}_{2}$ system.

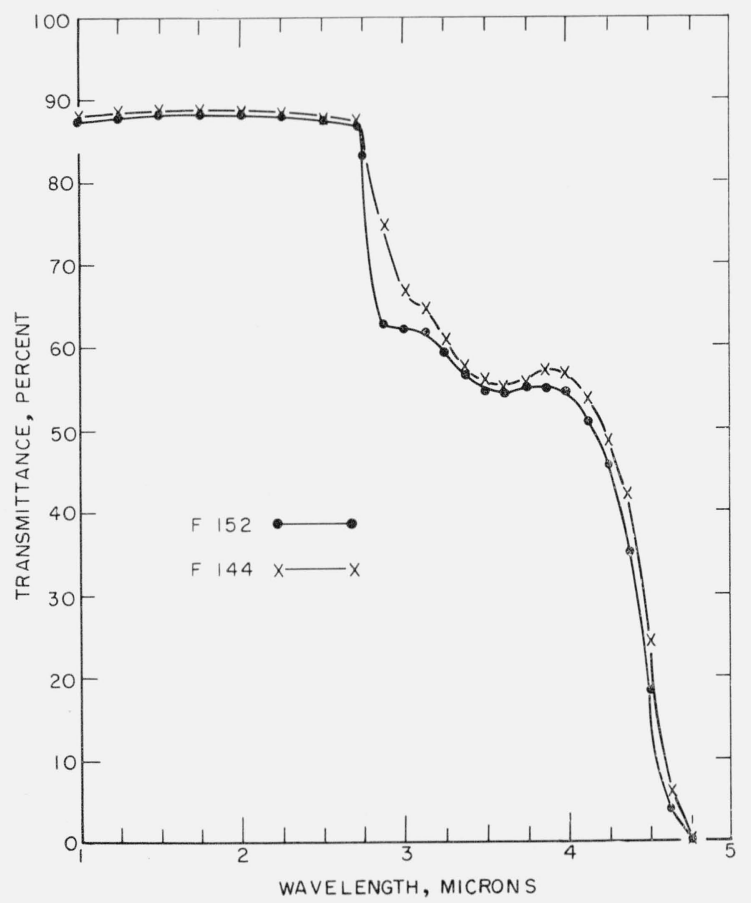

FiguRE 3. Spectral transmittance of 2-mm thickness of two glasses containing 5 mole percent of $\mathrm{TiO}_{2}$.

See table 1 for compositions of glasses.

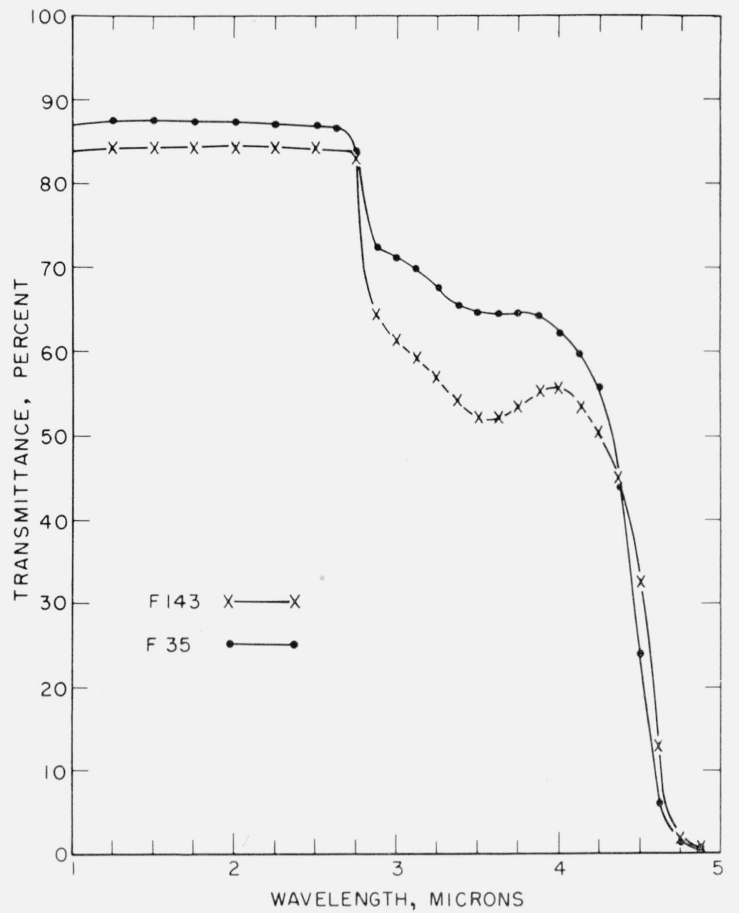

Figure 4. Spectral transmittance of 2-mm thickness of two glasses containing 10 mole percent of $\mathrm{TiO}_{2}$.

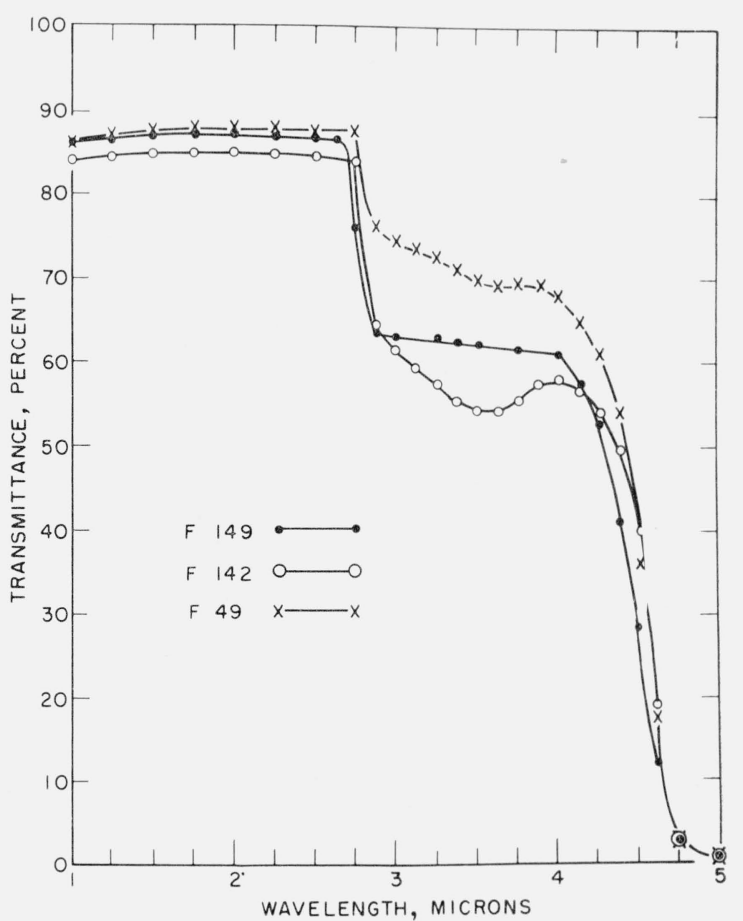

FIGURE 5. Spectral transmittance of 2-mm thickness of three glasses containing 15 mole percent of $\mathrm{TiO}_{2}$.

321 


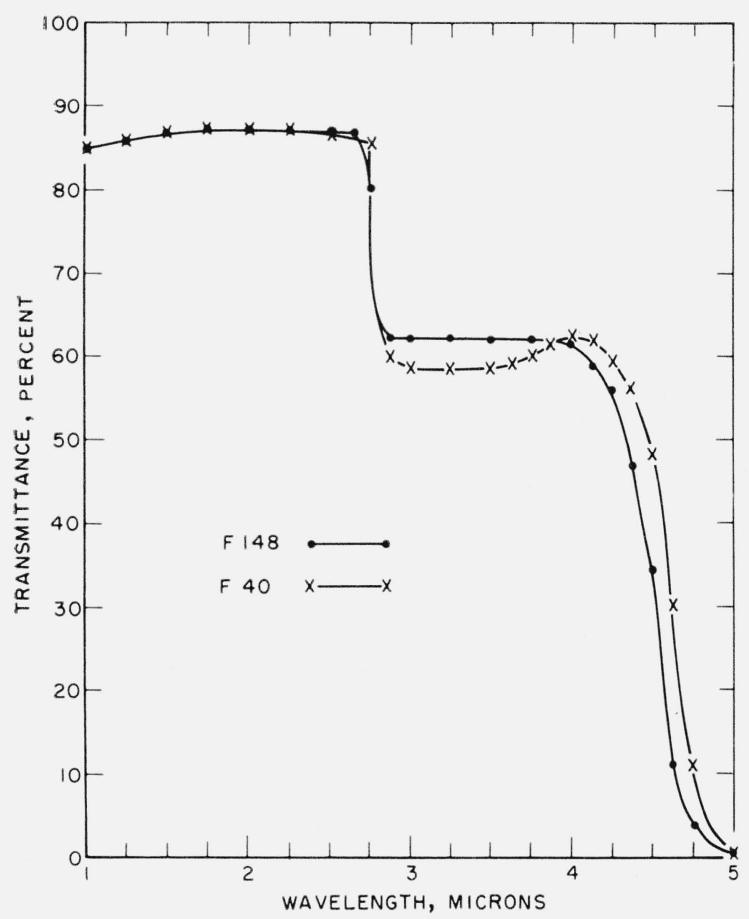

Figure 6. Spectral transmittance of 2-mm thickness of two glasses containing 20 mole percent of $\mathrm{TiO}_{2}$.

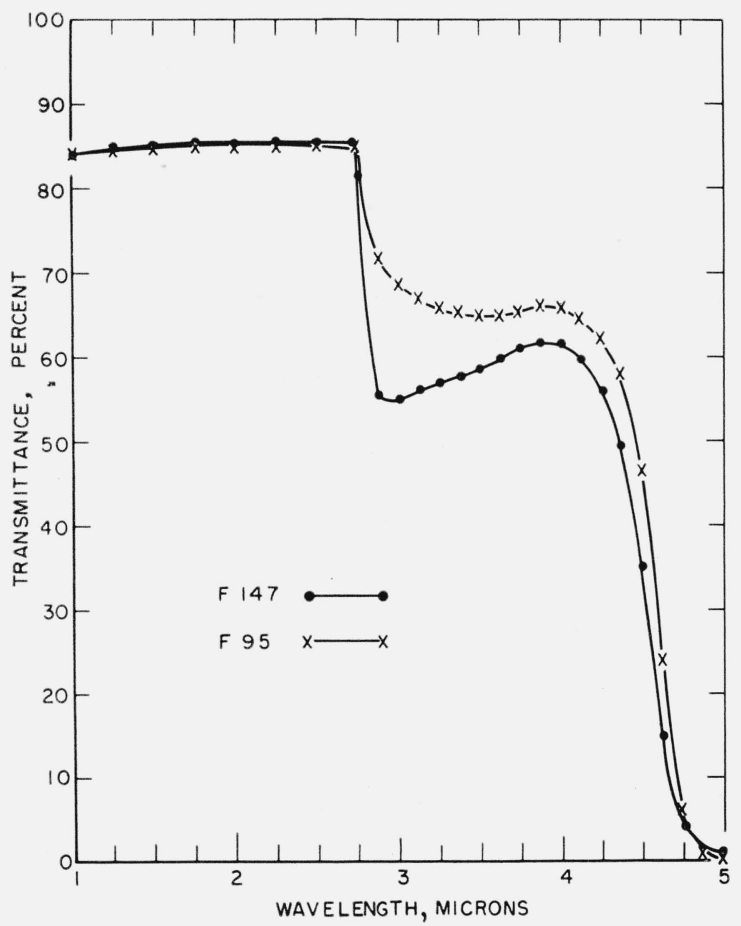

Figure 7. Spectral transmittance of 2-mm thickness of two glasses containing 25 mole percent of $\mathrm{TiO}_{2}$.

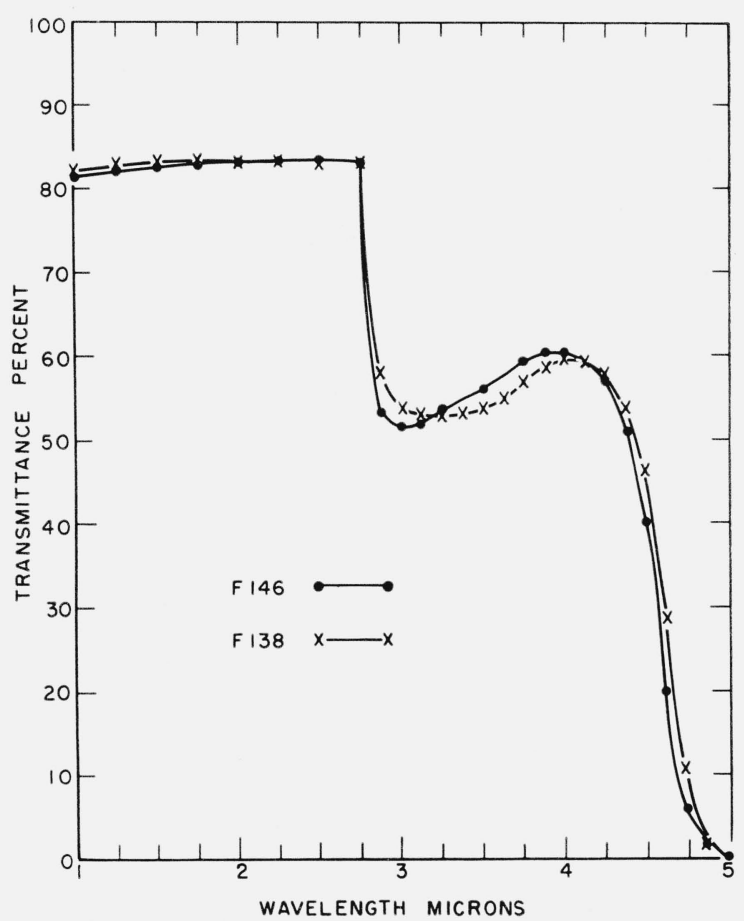

FIgURE 8. Spectral transmittance of 2-mm thickness of two glasses containing 30 mole percent of $\mathrm{TiO}_{2}$.

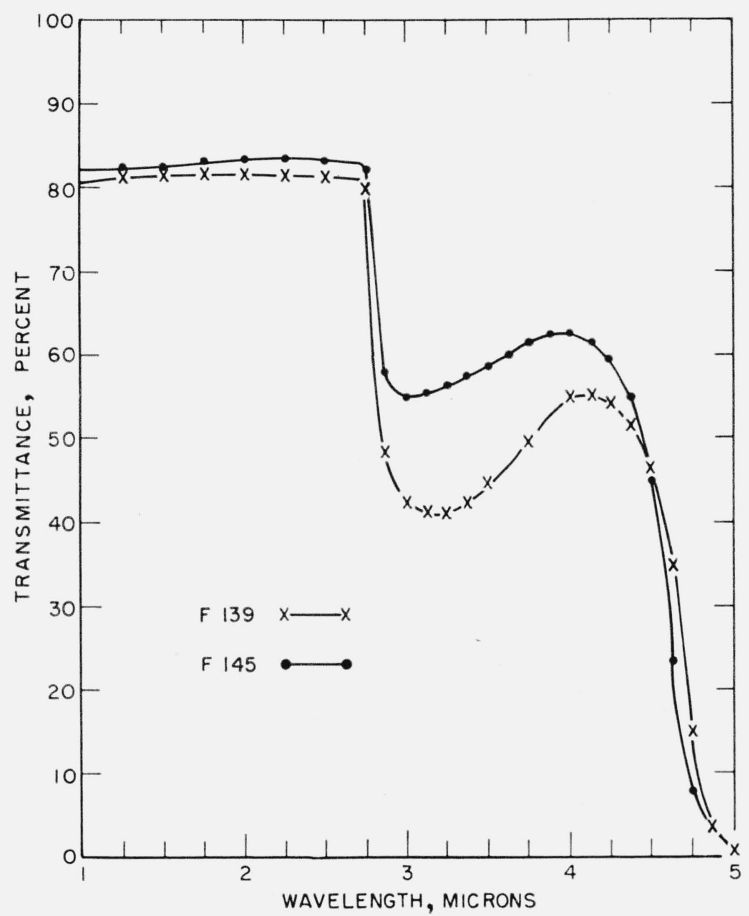

FIGURE 9. Spectral transmittance of 2-mm thickness of two glasses containing 35 mole percent of $\mathrm{TiO}_{2}$. 


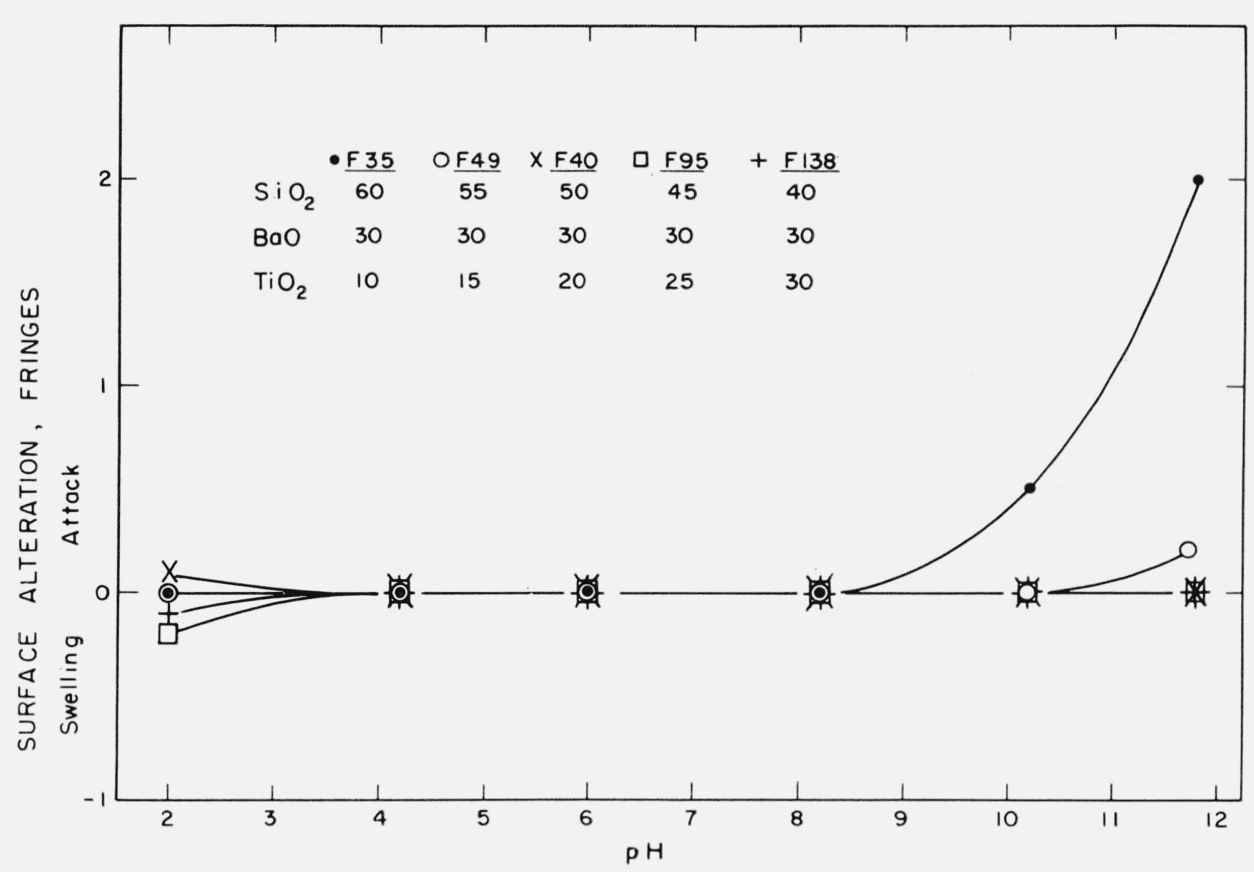

Figure 10. Chemical durability of five $\mathrm{BaO}-\mathrm{TiO}_{2}-\mathrm{SiO}_{2}$ glasses as a function of $p \mathrm{H}$.

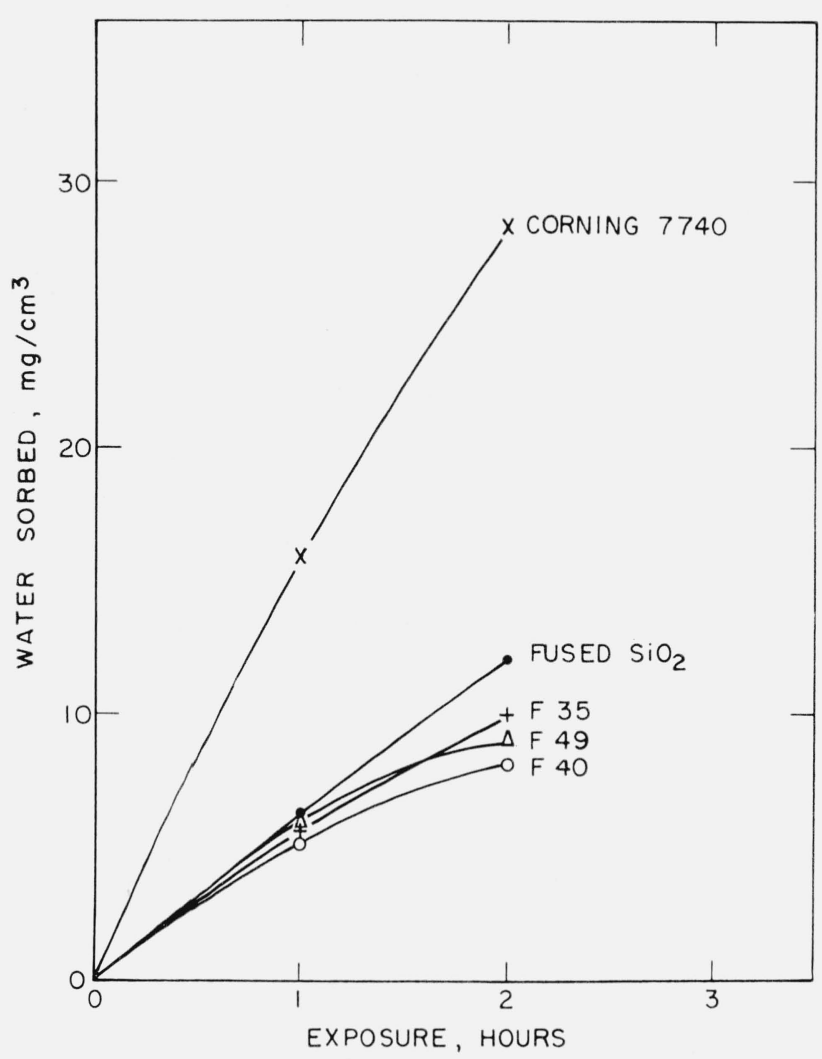

FIgUre 11. Hygroscopicity of three $\mathrm{BaO}-\mathrm{TiO}_{2}-\mathrm{SiO}_{2}$ glasses compared with Corning $7 \gamma_{4} 0$ glass and fused $\mathrm{SiO}_{2}$.

Washington, July 11, 1956.

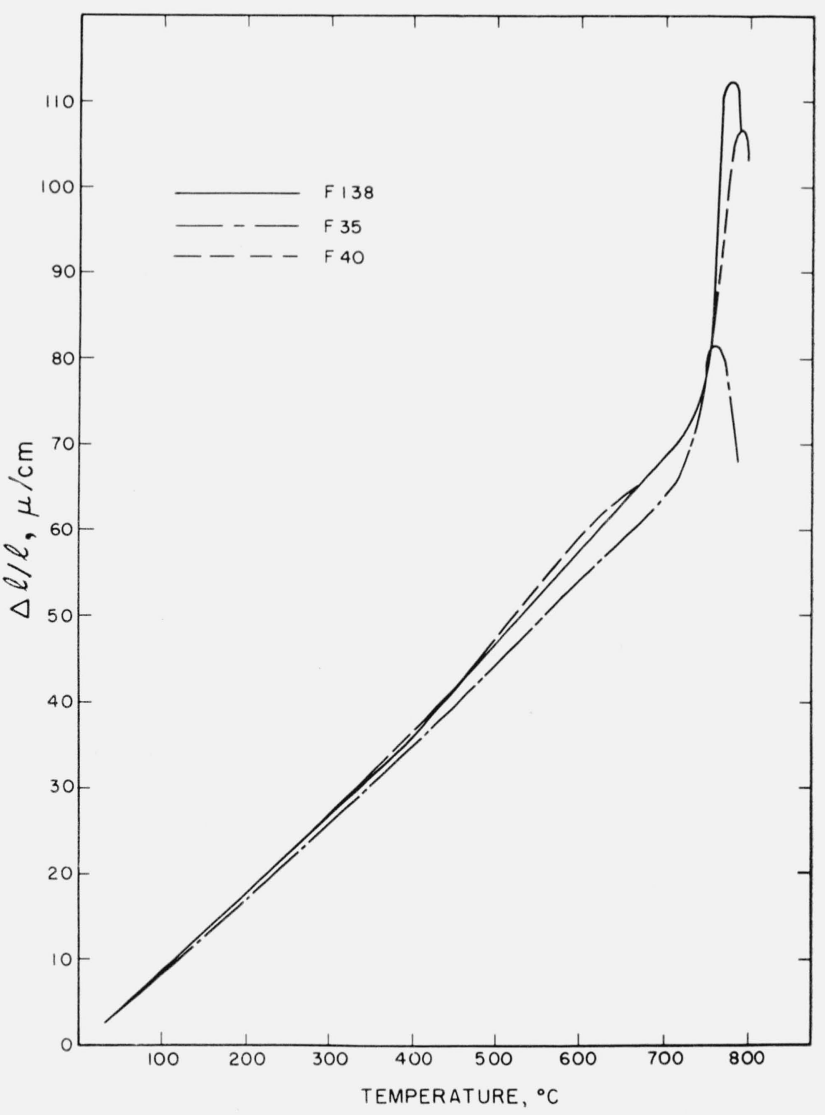

Figure 12. Thermal expansion curves of three $\mathrm{BaO}-\mathrm{TiO}_{2}-\mathrm{SiO}_{2}$ glasses as determined by an interferometric method. 